"information forwarded by life...". A more objective and perhaps humble analysis of past searching for improvement, less censorious but critical where something could be learnt, would have been more acceptable. It would have progress in Africa with that in South for social scientists; it has nothing for been illuminating to have a comparison of America. The book may have something

agriculturalists.

There are nine pages of references and an index of 18 pages. In neither is Borlaug's name mentioned.

D.L. Gunn, now retired, has been Director of the International Red Locust Control Service, Northern Rhodesia, Director of the Tea Research Institute, Ceylon, and Adviser to the Secretary of the Agricultural Research Council, London, UK.

\section{African mammal palaeontology}

Evolution of African Mammals. Edited by V. J. Maglio and H. B. S. Cooke Pp.641. (Harvard University Press: London and Cambridge, Massachusetts, 1978.) £42; $\$ 60$.

POtential READERS should clearly appreciate that this volume represents the first effort to put together in one book complete overviews of all African mammal groups. I want to congratulate the editors, Maglio and Cooke, for providing the impetus which led each of many specialists to articulate for the first time the entire known African story of his group. It should be stressed that much of what is presented in this volume, both in terms of materials and discussion, is quite new.

Authoritative introductions on presentday mammals of Africa (Bigalke) and the geological development of the physical African setting (Cooke) set the stage for 27 systematic chapters. These vary greatly, and appropriately, in length and depth of treatment. Thrre can be little doubt but that the 95 pages by Howell represent the most complete and useful treatment available of the African evolution of the family of man, the Hominidae. The paper combines some provocative interpretations with admirably balanced consideration not only of the different African fossil sources, but also of the legion of opinions expressed on and around hominid evolution.

Several other larger contributions are particularly impressive and comprehensive, notably those on Proboscidea (Coppens, Maglio, Madden and Beden), Bovidae (Gentry), Suidae and Tayassuidae (Cooke and Wilkinson) and Equidae (Churcher and Richardson). There are also substantial chapters on mesozoic mammals (Crompton and Jenkins), Insectivora and Chiroptera (Butler), Rodentia and Lagomorpha (Lavocat), prosimian primates (Walker), Cercopithecidae and Parapithecidae (Simons and Delson), cenozoic apes (Simons, Andrews and Pilbeam), Ramapithecus (Simons and Pilbeam), Carnivora (Savage), Pholidota and Tubulidentata (Patterson), Hyraroidea (Meyer), Deinotherioidea and Barytherioidea (Harris), Rhinocerotidae
(Hooijer), Anthracotheriidae (Black), Hippopotamidae (Coryndon), Cervidae and Palaeomerycidae (Hamilton), Giraffidae (Churcher), Sirenia (Domning) and Cetacea (Barnes and Mitchell).

Some shorter papers on lesser known groups add fascination by the strangeness of the beasts they describe: Embrithopoda (Tanner), Moeritherioidea (Coppens and Beden), Chalicotheriidae (Butler), Tragulidae and Camelidae (Gentry). Maglio's summary chapter on faunal turnover and succession, distribution and endemism, will probably be extensively used in future zoogeographic and evolutionary studies.

Much as each of the 30 fine contributions in this volume deserves individual comment, in a review of this length I will have to be content with expressing some overall impressions. The chronology, geography and stratigraphy of fossil finds are exceptionally completely and lucidly covered in numerous tables, maps and discussions. The histories of early fossil finds and conclusions are full of interest, and occasional humour. For example, in Harris' work on deinotheres we are told: "'Buckland's (1835) quaint portrait of a mammal anchored to a river bank by its tusks while it slept preceded the discovery of deinothere hind limbs". Illustrations pinpointing precisely salient morphological differences or primitive-toadvanced series, like those provided by Gentry (p544), Crompton and Jenkins (pp45 and 50), Hamilton (p506) and others, are valuable in a reference book of this sort. It is regrettable that the book contains too few of them.

Bibliographical coverage is excellent, with only a few exceptions (for example, the lack of reference to White and Harris' (1977) major work on fossil suids in the chapter by Cooke and Wilkinson; omission of several papers on African Carnivora, for example, of M.G. Leakey, Howell and Petter; and only cursory reference to important contributions by other carnivore specialists, such as Hendey and Ewer, in the contribution by Savage; and because the phylogenetic status of Ramapithecus is by no means established, as Simons and Pilbeam readily admit in their paper on this taxon, the inclusion of a larger bibliography and debate pro and contra hominid status of Ramapithecus would have further added to the great interest of this chapter).
In several instances good reviews of past and ongoing debates make exciting reading, as in the discussion of cetacean origins and the phylogenetic position of the African Archaeoceti by Barnes and Mitchell. Fortunately for a palaeontological tour de force of this length several of the authors have the ability to bring their long-dead creatures to life again. The expression of such ability, from deliberations on brain size and locomotion in the earliest mammals (Crompton and Jenkins) and on the evolution of the anteating habit in aardvarks (Patterson), to questions about how deinotheres used their tusks (Harris) and about why sirenians speciate slowly (Domning), adds greatly to a real enjoyment of this book.

In the preface the editors remark: "Such overviews (as this one) are the only means of ... picking out our significant achievements and failures". On reading through the whole book others too may perceive, as I do, a disturbing failure common to a sizeable block of the present contributions. On the one hand many morphological details are given; on the other, conclusions on relationship (in some cases 'trees') are presented. But between these two there is often an hiatus; that is, it is difficult, at best, to extract precisely which morphological details are considered by the author pro, and which contra, his hypotheses of relationship. The reader is thus unable to test such hypotheses. In individual cases it is not clear whether the author has preferred to base his conclusions only on unsorted impressions; or whether he has used a particular methodology to arrive at clear statements supporting his conclusions, but has merely failed to articulate these statements to his readers. Several of the papers stress the paucity and fragmentary nature of the fossils. That such shortcomings do not justify a lack of methodology and clarity is shown by the fact that some contributors on the poorest fossil samples (for example, Crompton and Jenkins on Mesozoic mammals, Hamilton on Cervidae and Palaeomerycidae, Patterson on Pholidota and Tubulidentata, and others) are among those that make the clearest statements in support of their hypotheses of relationship.

This large, sturdy volume, in which printing, reproduction of illustrations, binding and indexing are all of high quality, is unique in fully representing present knowledge of African fossil mammals. Whether or not one's own interpretations (and indeed mode of interpretation) differ from any of those in Evolution of African Mammals, there is no better companion than this book for anyone, whether student or specialist, who is interested in African mammal palaeontology.

E.S. Vrba

E.S. Vrba is Head of the Department of Palaeontology and Palaeoanthropology at the Transvaal Museum, Pretoria, South Africa. 